\title{
The Adopting of Markov Analysis to Forecast the Operations Competitive Advantages of Mobile Phone Service Providers: The Case of Jordan*
}

\author{
Yazan Khalid Abed-Allah Migdadi \\ Business Administration \\ Yarmouk University, Irbid Jordan \\ E-mail: yazan.m@yu.edu.jo
}

\begin{abstract}
The aim of this paper is to adopt the Markov analysis to forecast the operations competitive advantages of mobile phone service providers in Jordan. Three service providers were investigated. The secondary data of each service provider over the period (2005-2010) was used for the purpose of study. The Markov analysis was used to develop the series of forecasted competitive position index for each service provider, and then regression analysis was used to forecast the changes in operations competitive positions. The result showed that; the competitive position leader service provider which is Zain will be improved in term of network coverage, cost of calls services and network accessibility. But the follower (Orange) competitive position will be improved in term of cost of calls services, number of basic and entertainment services. The laggard (Umniah) competitive position will be deteriorated over time. This is the first study which adopts Markov analysis to forecast the operations competitive position. The managers of the corporations in Jordan have a clear insight about their future competitive position. The leader and follower can sustain their position, but the laggard should make further development in order to avoid the deterioration of its position. The scholar can benefit from the methodology of this paper to adopt Markov analysis to forecast the operations competitive position.
\end{abstract}

Keywords: markov analysis, operations, competitive advantage, service provider, mobile telecommunication, Jordan

\section{INTRODUCTION}

The operations strategy is one of the milestone topics of operations management. The research contribution of operations strategy is classified to process, content and context. The majority of research contribution is concentrated on reporting the operations competitive priorities (e.g. Wheelwright, 1984; Hill, 1995; Ward et al., 1996; Lee et al., 2007; Leseure, 2010; Paiva and Vieira, 2011). Reporting the forecasted operations competitive advantages is very important since the operations are the milestone for any organizations. Operations are responsible about delivering the finished products (good or services) to customers.

The competitive advantages have been investigated by the strategic management literature, the majority of previous studies of strategic management have developed conceptual models of competitive advantages (e.g. Passemard and
Kleiner, 2000; Beheshti, 2004; O'Shannassy, 2008; Javalgi, et al., 2011), and very limited studies have reported the practices of particular cases (e.g. Du, 2007; Hua et al., 2011). The empirical research contribution of competitive advantages in general and operations competitive advantages in particular is very limited. No previous study has adopted the Markov analysis to forecast the operations competitive advantages in general and mobile service providers competitive advantages in particular. The majority of previous studies of Markov analysis have focused on modeling the financial returns, students' enrollment at universities, and market share.

Reporting the sustained operations competitive advantages of mobile service providers is very important. This sector faces a strong competition especially in the Middle East region in general and Jordan in a particular. It is attractive to investigate the practices of mobile phone service providers in developing countries in general and particularly the practices of service providers in the Middle East region. The growth of this industry in developing economies is significantly more than developed countries. The developed countries growth is in a saturation stage. The Arab states region is the third ranked after Europe and the USA in terms of growth during 2009 to 2010 which reached $75 \%$ (International Telecommunication Union, 2010).

Jordan is a country located in the Middle East region. It a constitutional monarchy with a representative government.

The Jordan mobile market is characterized by a high competition between three mobile operators Zain, orange and Umniah. The leader and the first mover is the Zain. Which entered the market in 1996, followed by Orange in 2001 and the last entrant is Umniah, which entered the market in 2005 .

The contribution of information and communication sector in GDP is 14\% (Information Technology AssociationJordan, 2011). Jordan is the first country in the Middle and East and North Africa which liberalized its telecommunication sector (The Royal Bank of Scotland, 2011). The growth of mobile market in Jordan is about $7.1 \%$ annually, the penetration of $114 \%$, and this sector is expected to continue growing the next years (Business Monitor International, 2011)

This study will adopt Markov analysis to forecast the changes in operations competitive advantages for one of the leading sectors in Jordan. This study will bridge the literature gap and adopt a new methodology to forecast the competitive 
advantages. To realize this aim the following objectives were realized;

1. Identifying and defining the operations competitive capabilities of mobile phone service providers.

2. Developing the competitive position index of each service provider during the first period (2005) and second period (2010).

3. Developing the vector of competitive position probabilities of each service provider during the first period (2005).

4. Developing the matrix of transition probabilities for the competitive position of each service provider over the period (2005-2010).

5. Forecast the operational competitive position for each service provider according to each operations competitive capability over the period (2012-2031).

This paper is issued in five sections. The first one is the literature review, followed by the methodology section, then, data analysis and findings, the next section is the discussion, finally the conclusion, limitations, applications and future researches were presented.

\section{LITERATURE REVIEW}

\subsection{Markov Analysis}

It is a stochastic technique which is used to determine the future state of a particular phenomenon based on numerical calculations. It depends on probability of mutual impact over time (Mehmood and Lu, 2011). The first model was developed by Wienner in 1939 and 1940s. This model is widely used by social sciences to analyze the behavior of data panel. The applications in business are focused on brand switching, market structure and financial analysis. This model could be classified to single Markov chain (M) model, latent class (LC) models and Mixed of both which is called mixed Markov latent class Model (MMLC) (Aaltonen and Ostermark, 1998).

Building Markov forecasting model to predict the state of an object in a certain period of time in the future is the main principle of using Markov chain. Moreover, Markov chain prediction method is only a probability forecasting methods and the predicted results are expressed as a probability of a specific state in the future (Zhang \& Zhang, 2009).

In this technique, two states are assumed which are mutually exclusive and collectively exhaustive. Collectively exhaustive is a system in which all of the possible states can be listed. Mutually exclusive is a system that can be presented in only one state at any point in time. A matrix that containing all transition probabilities for a certain system is called Matrix of Transition Probabilities (Render, 2012).
The previous studies have focused on adopting Markov analysis to model financial returns (e.g. Aaltonen Ostermark, 1998; Chang, 2006), to model the controlling of maintenance management (e.g. Jin, et al., 2005), to forecast the future enrollment of students (e.g. Nyandwaki, et al. 2014), to forecast the future market share (e.g. Uslu et al., 2014), and energy demand (e.g. Kazemi et al., 2011). The previous studies have not adopted the Markov analysis to forecast the changes in operations competitive advantages for mobile phone service providers industry. Accordingly, this study will bridge this gap by adopting the Markov analysis principle.

\subsection{The Operations Competitive Advantages of Mobile Phone Service Providers}

The competitive advantage is one of the important concept in the strategic management literature. This concept had been discussed by numerous scholars of strategic management. There was a debate between scholars of strategic management about the proper definition of this concept. In the context of this research the competitive advantages are the consequences of strategic actions adopted by the organization. These advantages should be tangible on behalf of customers. The competitive advantages should be formulated on the product or services attributes in order to be recognized by customers.

The operations literature which discussed these attributes is the operations strategy literature. These attributes are titled as operations competitive capabilities, which are the realized operations competitive priorities. These capabilities could be classified to speed, cost, flexibility and quality (Skinner, 1969; Hill, 1995). The classification of these capabilities in the mobile service providers' operations strategy literature is proposed by Lee et al. (2006) and Migdadi (2012). These are reducing the prices, improving the service quality (service availability), billing system, range of service provided the offers.

The previous studies of operations strategy literature have focused mainly on reporting the manufacturing competitive priorities (e.g. Skinner, 1969, 1974; Wheelwright, 1984; Hill, 1995; Ward et al., 1996; Lee et al., 2007; Leseure, 2010; Paiva and Vieira, 2011). Further, these studies have not investigated the proposed future changes in the operations competitive capabilities. The majority of these studies are snap shot studies. Only one study has investigated the order winner operations strategy of mobile service providers (e.g. Migdadi, 2012). This study has focused on reporting the past practices of the leader, follower and laggard service providers over an extended period of time. This study did not investigate the future changes in the operations competitive advantages.

Table 1 The Sources of Competitive Capabilities And The Scales

\begin{tabular}{|c|c|}
\hline Source of competitive capabilities & Scale \\
\hline Network coverage & Percentage of population covered \\
\hline Diversity of offers & Number of offers \\
\hline Cost of calls service & Calls rate per minute \\
\hline Diversity of basic services & Number of basic services \\
\hline Diversity of entertainment services & Number of entertainment services \\
\hline Network accessibility & Percentage of unreachable calls \\
\hline
\end{tabular}


Table 2 Example (1) How to Compute The Competitive Position Index Of Orange Network Coverage

\begin{tabular}{|c|c|c|}
\hline Service provider & $\begin{array}{c}\text { Network } \\
\text { coverage (2005) }\end{array}$ & $\begin{array}{c}\text { Competitive } \\
\text { position index }\end{array}$ \\
\hline Zain & $85 \%$ & $85 \% / 90 \%=0.94$ \\
\hline Orange & $90 \%$ & $90 \% / 90 \%=1$ \\
\hline Umniah & $66 \%$ & $66 \% / 90 \%=0.73$ \\
\hline Best score & $90 \%$ & \\
\hline
\end{tabular}

Table 3 Example (3) How to Find the Transition Probability of Competitive Position

\begin{tabular}{|c|c|c|c|}
\hline $\begin{array}{c}\text { Service } \\
\text { provider }\end{array}$ & $\begin{array}{c}\text { Probability } \\
\text { of } \\
\text { competitive } \\
\text { position in } \\
2005\end{array}$ & $\begin{array}{c}\text { Probability of } \\
\text { competitive } \\
\text { position in } \\
\mathbf{2 0 1 1}\end{array}$ & $\begin{array}{c}\text { Difference (the } \\
\text { transaction in } \\
\text { probability of } \\
\text { competitive } \\
\text { position) }\end{array}$ \\
\hline Zain & 0.35 & 0.37 & 0.02 \\
\hline Orange & 0.37 & 0.36 & -0.01 \\
\hline umniah & 0.27 & 0.25 & -0.02 \\
\hline
\end{tabular}

The previous studies of strategic management have investigated the competitive advantages in general. The majority of the strategic management literature have focused on building conceptual models by using literature (e.g. Passemard and Kleiner, 2000; Beheshti, 2004; O'Shannassy, 2008; Javalgi, et al., 2011). Or investigating particular cases (e.g. Du, 2007; Hua et al., 2011). With limited concern about surveying a particular industry (e.g. Felzensztein and Gimmon, 2014) also the empirical studies are snap shot studies.

\section{METHODOLOGY}

The methodology of study passed through different stages as presented in Figure 1, each stage includes different steps. In the following sections are the details.

\subsection{Phase 1: Identifying and Defining the Operations Competitive Capabilities of Mobile Phone Service Providers}

The sources of operations competitive capabilities investigated in this study are very close to those recommended by Migdadi (2012) which are summarized in Table 1. The data was adopted from Migdadi (2012). Please see appendix (A).

\subsection{Phase 2: Developing the Competitive Position Index of Each Service Provider during the First Period (2005)}

The competitive position index is the relative performance index of each service provider in comparison with best competitors during the first period (2005). The performance indicators are the operations competitive capabilities. The competitive position index was developed for each service provider's competitive capability. The following procedures were followed for this purpose:

Step 1: the scores of each service provider's operations capabilities during the first period (2005) were identified.
The source of these scores is Migdadi (2012). The scores are presented in Appendix (A).

Step 2: identifying the best score realized by service providers under each competitive capability.

Step 3: the competitive capability score of each service provider was divided by the performance of the best score, if the capability higher score is the best. Or the best score was divided by the realized score of each service provider, if the capability lower score is the best (this is in the case of cost per minutes of call). See the example presented in Table 2.

\subsection{Phase 3: Developing the Vector of} Competitive Position Probabilities of Each Service Provider during the First Period

Step 1: Compute the competitive position index for each service provider (the same as discussed in phase 2).

Step 2: Computing the probability of competitive position of each service provider. This was made by summing the competitive position indices of all service providers, then divide the competitive position index score of each service provider by the total. See the following example

Example (2): how to develop the vector of competitive position probability

a. Summing the indices: $0.94+1+0.73=2.67$

b. Compute the probability:

Zain: $0.94 / 2.67=0.35$

Orange: $1 / 2.67=0.37$

Umniah $=0.73 / 2.67=0.27$

Step 3: Finally the results were placed into a victor of competitive position probability as presented below.
Zain
Orange
Umniah
$(0.35$
0.37
$0.28)$

\subsection{Phase 4: Developing the Matrix of Transition Probabilities for the Competitive Position of Each Service Provider \\ Step 1: compute the probability of competitive position} for each service provider over the first period (2005) and second period (2010) as discussed in section (3.3).

Step 2: find the differences between the probabilities of each service provider over the periods. This represents the probabilities of transitions. See the example presented in Table 3

Step 3: if the transition probabilities is negative the competitive position of service provider is deteriorated, so the whole probability which is (1) will be reduced by the amount of deterioration, and this deterioration represents an improvement in competitive position of other service providers' probabilities. For more details about all matrices of transition competitive position probability see Appendix (B).

Example (4): The Matrix of Transition Probabilities

$\left|\begin{array}{lll}\text { Zain } & \text { Orange } & \text { Umniah } \\ 1 & 0 & 0 \\ 0.0046 & 0.9954 & 0 \\ 0.0153 & 0 & 0.9847\end{array}\right|$




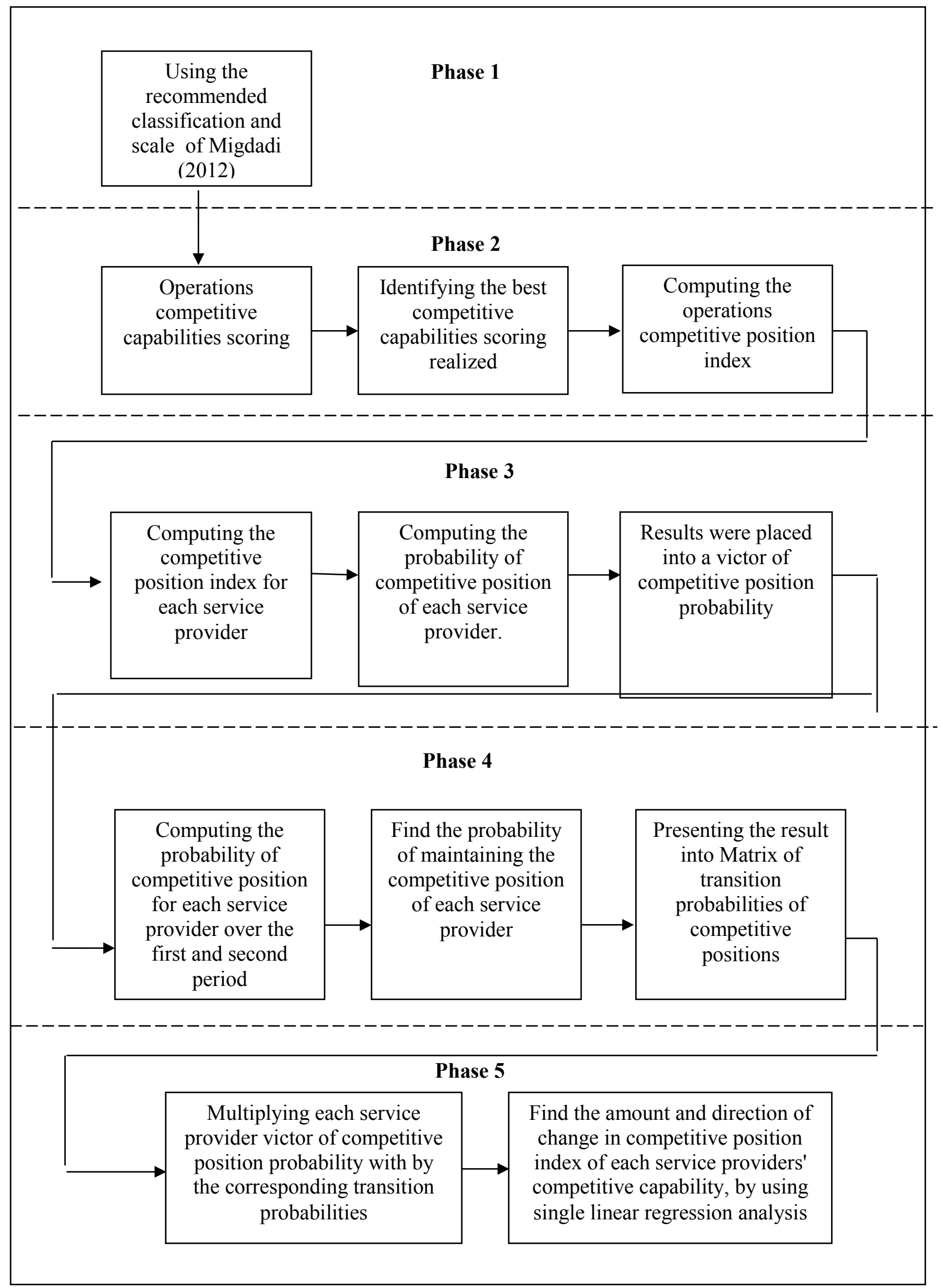

Figure 1 The Flow Chart of Study 
Example (5): How to Compute the Competitive Position Index According to Network Accessibility

\begin{tabular}{|c|c|c|c|c|c|}
\hline & & & Zain & Orange & Umniah \\
\hline Zain & Orange & Umniah & $\overline{1}$ & 0 & 0 \\
\hline$(0.35$ & 0.37 & $0.28)$ & 0.0046 & 0.9954 & 0 \\
\hline & & & 0.0153 & 0 & 0.9847 \\
\hline
\end{tabular}

Zain competitive position over the first period $=(0.35 * 1)+(0.37 * 0.0046)+(0.28 * 0.0153)=0.36$

Orange competitive position over the first period $=(0.35 * 0)+(0.37 * 0.9954)+(0.28 * 0)=0.3$

Umniah competitive position over the first period $=(0.35 * 0)+(0.37 * 0.0)+(0.28 * 0.9847)=0.28$

\subsection{Phase 5: Forecast the Operational Competitive Position for Each Service Provider According to Each Operations Competitive Capability}

Step 1: each service provider victor of competitive position probability was multiplied by the corresponding transition probabilities. This action was repeated 20 times since the period of investigation was extended over the period (2011-2031)

Step 2: Then, in order to find the amount and direction of change in competitive position index of each service providers' competitive capability, single linear regression analysis was used for this purpose.

\section{DATA ANALYSIS AND FINDINGS}

This section represents the results of linear regression analysis to identify the operations competitive advantages. The following sections are the results related to each service provider.

\subsection{The Operations Competitive Advantages of Zain Corporation}

Figure 2 shows the changes in the probability of competitive advantage of Zain Corporation over time. It can be seen that; the competitive position of Zain Corporation in term of network coverage, cost of calls services and network accessibility are improved over time. However, the competitive position of Zain Corporation in term of diversity of offers, diversity of entertainment service will be deteriorated over time, but the competitive position of diversity of basic services will not change over time. Table 4 shows the computed probabilities of competitive advantages over time and result of linear regression analysis, it can be seen that; the probability of competitive position of network accessibility will reach 0.47 in 2031, however, the probability of competitive position of calls rate per minute will reach 0.71 in 2031 . The competitive position index of network accessibility will reach 0.25 in 2031. The probability of number of offers, number of entertainment services will be deteriorated to reach 0.18 and 0.21 in 2031 respectively. The corporation is expected to maintain its position without change in term of basic services.

Linear regression analysis result reports the average change in the probability of competitive position. It can be seen that in Table 4; the coefficient of linear regression models represents such change, the average probability change in network coverage, cost if calls services and service accessibility is positive, the change is $0.005,0.24$ and 0.0012 respectively, so the probability of competitive positions will be improved. The average probability change in term of number of offers and number of entertainment services is negative; the change is -0.009 , and -0.004 respectively, so the probability of competitive position will be deteriorated.

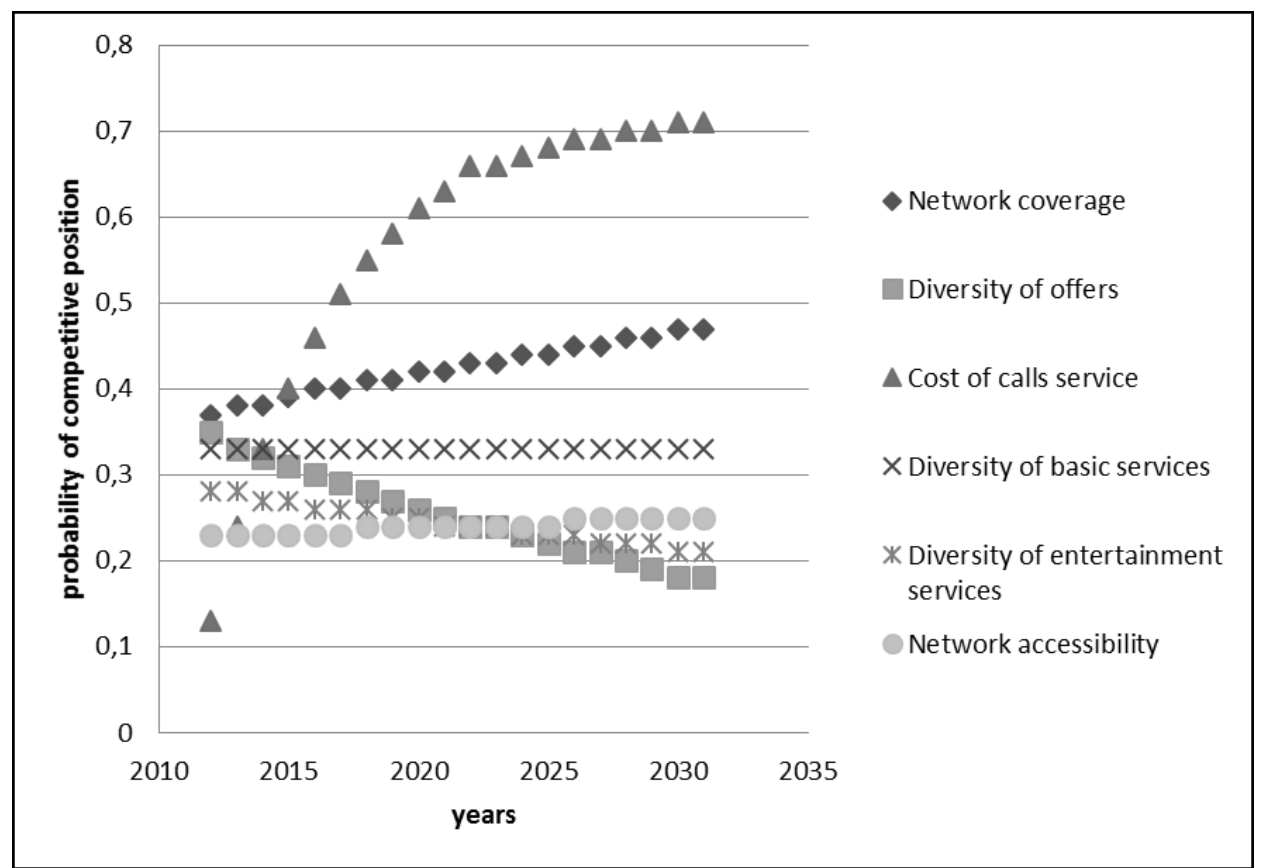

Figure 2 The scatter diagram for the changes in the probability of Zain Corporation's operations competitive position over time period (2012-2031) 
Table 4 The Analysis of Zain Corporation's Operations Competitive Advantages

\begin{tabular}{|c|c|c|c|c|c|c|}
\hline Year & $\begin{array}{c}\text { Network } \\
\text { coverage }\end{array}$ & $\begin{array}{c}\text { Diversity of } \\
\text { offers }\end{array}$ & $\begin{array}{c}\text { Cost of calls } \\
\text { service }\end{array}$ & $\begin{array}{c}\text { Diversity of } \\
\text { basic } \\
\text { services }\end{array}$ & $\begin{array}{c}\text { Diversity of } \\
\text { entertainment } \\
\text { services }\end{array}$ & $\begin{array}{c}\text { Network } \\
\text { accessibility }\end{array}$ \\
\hline 2012 & 0.37 & 0.35 & 0.13 & 0.33 & 0.28 & 0.23 \\
\hline 2013 & 0.38 & 0.33 & 0.24 & 0.33 & 0.28 & 0.23 \\
\hline 2014 & 0.38 & 0.32 & 0.33 & 0.33 & 0.27 & 0.23 \\
\hline 2015 & 0.39 & 0.31 & 0.40 & 0.33 & 0.27 & 0.23 \\
\hline 2016 & 0.40 & 0.30 & 0.46 & 0.33 & 0.26 & 0.23 \\
\hline 2017 & 0.40 & 0.29 & 0.51 & 0.33 & 0.26 & 0.23 \\
\hline 2018 & 0.41 & 0.28 & 0.55 & 0.33 & 0.26 & 0.24 \\
\hline 2019 & 0.41 & 0.27 & 0.58 & 0.33 & 0.25 & 0.24 \\
\hline 2020 & 0.42 & 0.26 & 0.61 & 0.33 & 0.25 & 0.24 \\
\hline 2021 & 0.42 & 0.25 & 0.63 & 0.33 & 0.24 & 0.24 \\
\hline 2022 & 0.43 & 0.24 & 0.66 & 0.33 & 0.24 & 0.24 \\
\hline 2023 & 0.43 & 0.24 & 0.66 & 0.33 & 0.24 & 0.24 \\
\hline 2024 & 0.44 & 0.23 & 0.67 & 0.33 & 0.23 & 0.24 \\
\hline 2025 & 0.44 & 0.22 & 0.68 & 0.33 & 0.23 & 0.24 \\
\hline 2026 & 0.45 & 0.21 & 0.69 & 0.33 & 0.23 & 0.25 \\
\hline 2027 & 0.45 & 0.21 & 0.69 & 0.33 & 0.22 & 0.25 \\
\hline 2028 & 0.46 & 0.20 & 0.70 & 0.33 & 0.22 & 0.25 \\
\hline 2029 & 0.46 & 0.19 & 0.70 & 0.33 & 0.22 & 0.25 \\
\hline 2030 & 0.47 & 0.18 & 0.71 & 0.33 & 0.21 & 0.25 \\
\hline 2031 & 0.47 & 0.18 & 0.71 & 0.33 & 0.21 & 0.25 \\
\hline & Linear| regression analysis for the impact of time on the probability of competitive position \\
\hline R & 0.99 & 0.99 & 0.88 & 1.00 & 0.99 & 0.98 \\
\hline F-value & $6140.76^{* *}$ & $1626.73^{* *}$ & $66.81^{* *}$ & $0.00^{* *}$ & $5183^{* *}$ & $856.4^{* *}$ \\
\hline P-value & 0.000 & 0.000 & 0.000 & 0.00 & 0.000 & 0.000 \\
\hline Intercept & $10.32^{* *}$ & $17.8^{* *}$ & $-48.23^{* *}$ & $0.33^{* *}$ & $7.74^{* *}$ & $-2.21^{* *}$ \\
\hline $\mathrm{t}-$-value & -75.62 & 40.81 & -8.07 & 0.001 & 74.3 & -26.40 \\
\hline P-value & 0.000 & 0.000 & 0.000 & 0.000 & 0.000 & 0.000 \\
\hline Coefficient & $0.005^{* *}$ & $-0.009^{* *}$ & $0.24^{* *}$ & 0 & $-0.004^{* *}$ & $0.0012^{* *}$ \\
\hline t-value & 78.36 & -40.33 & 8.17 & 0 & -71.99 & 29.27 \\
\hline P-value & 0.000 & 0.000 & 0.000 & 1 & 0.000 & 0.000 \\
\hline
\end{tabular}

**P-value $\leq 0.01$

\subsection{The Operations Competitive Advantages of Orange Corporation}

Figure 3 shows the changes in the probability of competitive advantage of Orange Corporation over time. It can be seen that; the probability of competitive position of Orange Corporation in term of cost of calls services, number of basic services and number of entertainment services will be improved over time. However, the probability of competitive position of Orange Corporation in term of network coverage, diversity of offers, and network accessibility will be deteriorated over time. Table 5 shows the computed probabilities of competitive advantages over time and result of linear regression analysis, it can be seen that; the probability of competitive position of calls rate per minute will reach 0.28 in 2031. The probability of competitive position index of basics services will reach 0.46 in 2031. The probability of competitive position index of number of entertainment services will reach 0.48 in 2031. The probability of network coverage, number of offers, and network accessibility will be deteriorated to reach $0.34,0.19$ and 0.11 in 2031 respectively.

Linear regression analysis result reports the average change in the probability of competitive position. It can be seen that in Table 5; the coefficient of linear regression models represents such change, the average probability of change in cost of calls services, number of basic services and number of entertainment services is positive, the change is $0.006,0.0083$ and 0.006 respectively, so the probability of competitive positions will be improved. The average probability change in term of network coverage, number of offers and network accessibility is negative, the change is $0.0016,-0.014$ and -0.061 respectively, so the probability of competitive position will be deteriorated. 


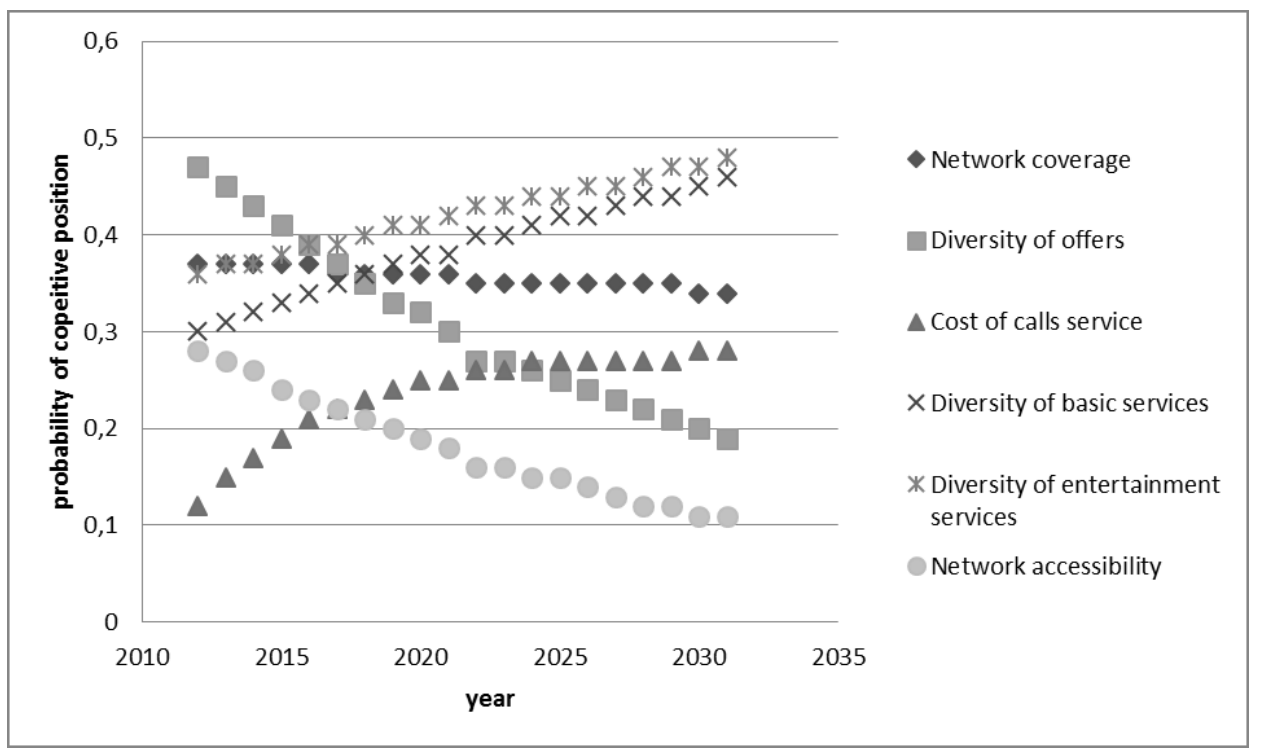

Figure 3 The Scatter Diagram for the Changes in the Probability of Orange Corporation's Operations Competitive Position over Time Period (2012-2031)

Table 5 The Analysis of Orange Corporation's Operations Competitive Advantages

\begin{tabular}{|c|c|c|c|c|c|c|}
\hline Year & $\begin{array}{l}\text { Network } \\
\text { coverage }\end{array}$ & $\begin{array}{l}\text { Diversity of } \\
\text { offers }\end{array}$ & $\begin{array}{l}\text { Cost of calls } \\
\text { service }\end{array}$ & $\begin{array}{c}\text { Diversity of } \\
\text { basic services }\end{array}$ & $\begin{array}{l}\text { Diversity of } \\
\text { entertainment } \\
\text { services }\end{array}$ & $\begin{array}{c}\text { Network } \\
\text { accessibility }\end{array}$ \\
\hline 2012 & 0.37 & 0.47 & 0.12 & 0.30 & 0.36 & 0.28 \\
\hline 2013 & 0.37 & 0.45 & 0.15 & 0.31 & 0.37 & 0.27 \\
\hline 2014 & 0.37 & 0.43 & 0.17 & 0.32 & 0.37 & 0.26 \\
\hline 2015 & 0.37 & 0.41 & 0.19 & 0.33 & 0.38 & 0.24 \\
\hline 2016 & 0.37 & 0.39 & 0.21 & 0.34 & 0.39 & 0.23 \\
\hline 2017 & 0.36 & 0.37 & 0.22 & 0.35 & 0.39 & 0.22 \\
\hline 2018 & 0.36 & 0.35 & 0.23 & 0.36 & 0.40 & 0.21 \\
\hline 2019 & 0.36 & 0.33 & 0.24 & 0.37 & 0.41 & 0.20 \\
\hline 2020 & 0.36 & 0.32 & 0.25 & 0.38 & 0.41 & 0.19 \\
\hline 2021 & 0.36 & 0.30 & 0.25 & 0.38 & 0.42 & 0.18 \\
\hline 2022 & 0.35 & 0.27 & 0.26 & 0.40 & 0.43 & 0.16 \\
\hline 2023 & 0.35 & 0.27 & 0.26 & 0.40 & 0.43 & 0.16 \\
\hline 2024 & 0.35 & 0.26 & 0.27 & 0.41 & 0.44 & 0.15 \\
\hline 2025 & 0.35 & 0.25 & 0.27 & 0.42 & 0.44 & 0.15 \\
\hline 2026 & 0.35 & 0.24 & 0.27 & 0.42 & 0.45 & 0.14 \\
\hline 2027 & 0.35 & 0.23 & 0.27 & 0.43 & 0.45 & 0.13 \\
\hline 2028 & 0.35 & 0.22 & 0.27 & 0.44 & 0.46 & 0.12 \\
\hline 2029 & 0.35 & 0.21 & 0.27 & 0.44 & 0.47 & 0.12 \\
\hline 2030 & 0.34 & 0.20 & 0.28 & 0.45 & 0.47 & 0.11 \\
\hline 2031 & 0.34 & 0.19 & 0.28 & 0.46 & 0.48 & 0.11 \\
\hline \multicolumn{7}{|c|}{ Linear regression analysis for the impact of time on the probability of competitive position } \\
\hline $\mathrm{R}^{2}$ & 0.99 & 0.99 & 0.88 & 0.99 & 0.99 & 0.99 \\
\hline F-value & $16102.3^{* *}$ & $930.51^{* *}$ & $66.81^{* *}$ & $2079.57^{* *}$ & $6625^{\star *}$ & $856.45^{\star *}$ \\
\hline$P$-value & 0.000 & 0.000 & 0.000 & 0.000 & 0.000 & 0.000 \\
\hline Intercept & $3.7^{\star *}$ & $29.4^{\star \star}$ & $-12.89^{* \star}$ & $-16.45^{\star \star}$ & $-11.88^{\star \star}$ & $18.19^{\star \star}$ \\
\hline t-value & 111.2 & 30.82 & -8.02 & -44.5 & -78.59 & 29.55 \\
\hline P-value & 0.000 & 0.000 & 0.000 & 0.000 & 0.000 & 0.000 \\
\hline Coefficient & $-0.0016^{* *}$ & $-0.0144^{* *}$ & $0.006^{* *}$ & $0.0083^{* *}$ & $0.006^{* \star}$ & $-0.0609^{* *}$ \\
\hline t-value & -100.512 & -30.501 & 8.17 & 45.602 & 81.40 & -29.26 \\
\hline P-value & 0.000 & 0.000 & 0.000 & 0.000 & 0.000 & 0.000 \\
\hline
\end{tabular}

$* *$ P-value $\leq 0.01$ 


\subsection{The Operations Competitive Advantages of Umniah Corporation \\ Figure 4 shows the change in probability of} competitive advantages analysis of Umniah Corporation. It can be seen that; the probability of competitive position of Umniah Corporation in term of all operations competitive capabilities will be deteriorated overtime. Table 6 shows the computed probabilities of competitive advantages over time and result of linear regression analysis, it can be seen that; the probability of competitive position index will reach 0.01 for network coverage, diversity of entertainment services in 2031. The probability of competitive position index will reach 0.02 for diversity of basic services and network accessibility in 2031 . The probability of competitive position index of diversity of offers and cost of call services will reach 0.03 in 2031.

The competitive position indices over time will be deteriorated as presented by the linear regression analysis results. The change is about -0.0036 (coefficient value) annually for network coverage. The change is about -0.0079 for the network accessories. The change is about -0.0084 (coefficient value) annually for diversity of basic services. The change is about -0.0024 (coefficient value) annually for the diversity of entertainment services. The change is about -0.024 (coefficient value) annually for diversity of offers. The change is about -0.033 for cost of calls services.

Table 6 The Analysis of Umniah Corporation's Operations Competitive Advantages

\begin{tabular}{|c|c|c|c|c|c|c|}
\hline Year & $\begin{array}{l}\text { Network } \\
\text { coverage }\end{array}$ & $\begin{array}{l}\text { Diversity of } \\
\text { offers }\end{array}$ & $\begin{array}{l}\text { Cost of calls } \\
\text { service }\end{array}$ & $\begin{array}{c}\text { Diversity of } \\
\text { basic services }\end{array}$ & $\begin{array}{l}\text { Diversity of } \\
\text { entertainment } \\
\text { services }\end{array}$ & $\begin{array}{c}\text { Network } \\
\text { accessibility }\end{array}$ \\
\hline 2012 & 0.28 & 0.58 & 0.68 & 0.41 & 0.32 & 0.41 \\
\hline 2013 & 0.24 & 0.49 & 0.58 & 0.35 & 0.27 & 0.34 \\
\hline 2014 & 0.20 & 0.42 & 0.49 & 0.3 & 0.23 & 0.29 \\
\hline 2015 & 0.17 & 0.36 & 0.42 & 0.25 & 0.2 & 0.25 \\
\hline 2016 & 0.15 & 0.3 & 0.35 & 0.22 & 0.17 & 0.21 \\
\hline 2017 & 0.13 & 0.26 & 0.3 & 0.18 & 0.14 & 0.18 \\
\hline 2018 & 0.11 & 0.22 & 0.26 & 0.16 & 0.12 & 0.15 \\
\hline 2019 & 0.09 & 0.19 & 0.22 & 0.13 & 0.10 & 0.13 \\
\hline 2020 & 0.08 & 0.16 & 0.19 & 0.11 & 0.09 & 0.11 \\
\hline 2021 & 0.07 & 0.13 & 0.16 & 0.1 & 0.07 & 0.09 \\
\hline 2022 & 0.06 & 0.11 & 0.13 & 0.08 & 0.06 & 0.08 \\
\hline 2023 & 0.05 & 0.1 & 0.11 & 0.07 & 0.05 & 0.07 \\
\hline 2024 & 0.04 & 0.08 & 0.10 & 0.06 & 0.05 & 0.06 \\
\hline 2025 & 0.03 & 0.07 & 0.08 & 0.05 & 0.04 & 0.05 \\
\hline 2026 & 0.03 & 0.06 & 0.07 & 0.04 & 0.03 & 0.04 \\
\hline 2027 & 0.02 & 0.05 & 0.06 & 0.04 & 0.03 & 0.04 \\
\hline 2028 & 0.02 & 0.04 & 0.05 & 0.03 & 0.02 & 0.03 \\
\hline 2029 & 0.02 & 0.04 & 0.04 & 0.03 & 0.02 & 0.03 \\
\hline 2030 & 0.02 & 0.03 & 0.04 & 0.02 & 0.02 & 0.02 \\
\hline 2031 & 0.01 & 0.03 & 0.03 & 0.02 & 0.01 & 0.02 \\
\hline \multicolumn{7}{|c|}{ Linear regression analysis for the impact of time on the probability of competitive position } \\
\hline $\mathrm{R}^{2}$ & 0.99 & 0.99 & 0.89 & 0.99 & 0.99 & 0.99 \\
\hline F-value & $4879.6^{\star *}$ & $1148.24^{\star *}$ & $69.17^{\star *}$ & $2073.9^{* *}$ & $8643^{* *}$ & $876.84^{\star *}$ \\
\hline P-value & 0.000 & 0.000 & 0.000 & 0.000 & 0.000 & 0.000 \\
\hline Intercept & $7.63^{* *}$ & $-47.21^{* *}$ & $66.27^{* *}$ & $17.37^{* *}$ & $5.16^{\star *}$ & $-15.34^{* *}$ \\
\hline t-value & 72.1 & -33.57 & 8.34 & 46.29 & 99.45 & -28.53 \\
\hline P-value & 0.000 & 0.000 & 0.000 & 0.000 & 0.000 & 0.000 \\
\hline Coefficient & $-0.0036^{* *}$ & $-0.024^{* \star}$ & $-0.033^{* \star}$ & $-0.0084^{* *}$ & $-0.0024^{* *}$ & $-0.0079^{\star *}$ \\
\hline t-value & -69.85 & -33.88 & -8.31 & -45.54 & -92.96 & -29.61 \\
\hline P-value & 0.000 & 0.000 & 0.00 & 0.000 & 0.000 & 0.000 \\
\hline
\end{tabular}




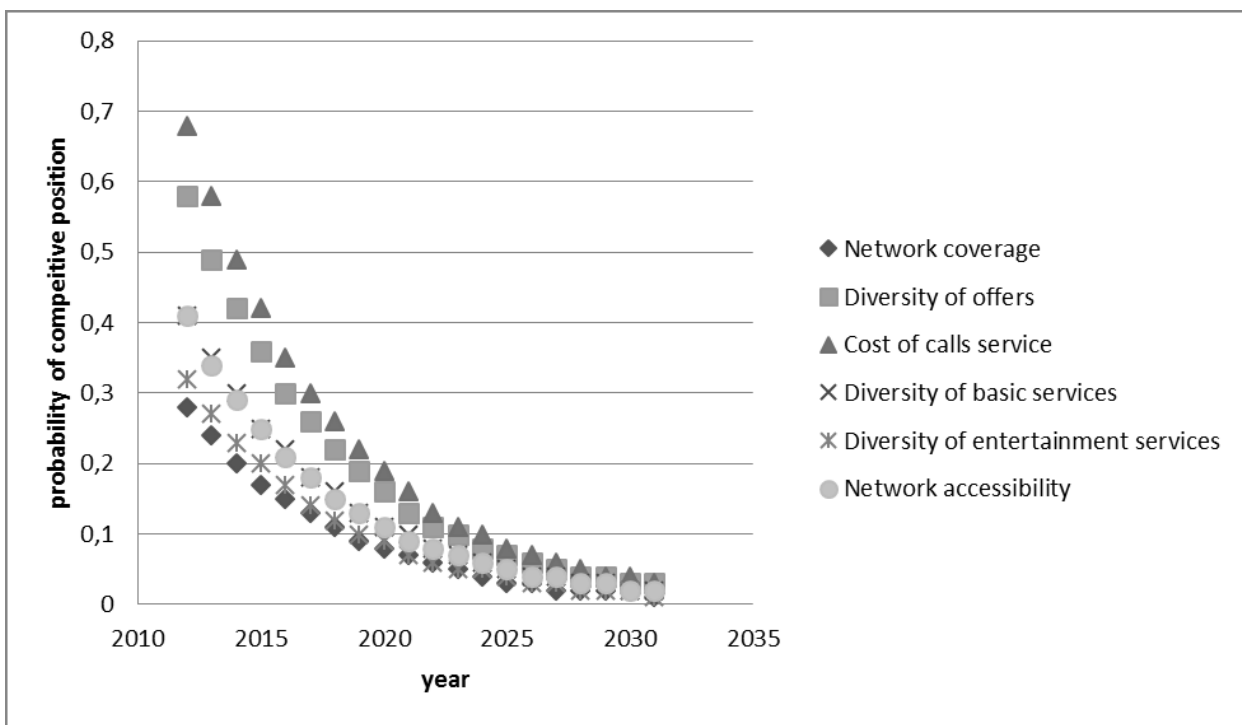

Figure 4 The Scatter Diagram for the Changes in the Probability of Umniah Corporation's Operations Competitive Position over Time Period (2012-2031)

\section{DISCUSSION}

The combinations of operations competitive advantages that will be improved for Zain differ from Orange. This indicates that; each service provider should have different sources of competitive advantages over time in order to have a position on the market especially for a market faces sever completion like Jordan market.

The time of market entry could justify the results of this study; Zain Corporation was the early mover for the Jordan market, this corporation monopolizes the telecom market in Jordan for about five years. In general the early movers are expected to occupy the best position over time. The next service provider entered the market after Zain was Orange and the last service provider entered the market was Umnaih after five years of Orange corporation entry. So the late entrant is expected to face worse competitive position in comparison with the second mover.

The improved operations competitive advantages over time of Zain were network coverage, cost of calls services and network accessibility. This result is logical since the early mover are already invest heavily in the assets to attract more subscribers and reduce the cost per base station, further, Jordan is a small country so the early movers will gain the benefit (Migdadi, 2012). However, the improved operations competitive advantages over time of Orange were; cost of calls services, number of basic services and number of entertainment services. This result is logical, if the service provider have not such advantages of early mover it should differentiate itself by launching more services, whether basic or entertainment, one other hand, the shared improved advantage between both service providers is cost, since customers in Jordan the same as customers in other developing economies are attracted by cost (Migdadi, 2012).

\section{CONCLUSION}

\subsection{Contribution and Result}

The previous studies of operations strategy have focused on mainly on reporting the operations competitive priorities. The operations competitive advantages have not been reported by the previous studies of operations strategy.
The competitive advantages have been studied by the strategic management literature, the focus of the previous studies was on developing conceptual models or investigating particular cases. The previous studies of Markov analysis have not reported the operations competitive advantages. The studies have focused on modeling financial returns, students' enrollment, and market share. This study is the first study which used the Markov analysis to forecast the operations competitive advantages of mobile service providers.

The main result of this study is that the competitive position leader service provider which is Zain will be improved in term of network coverage, cost of calls services and network accessibility. But the follower (Orange) competitive position will be improved in term of cost of calls services, number of basic and entertainment services. The laggard (Umniah) competitive position will be deteriorated over time.

\subsection{Implications, Limitations and Future Researches}

This study developed a methodology to adopt Markov analysis to forecast the operations competitive advantages. This methodology could be adopted by future scholar in the same or other industries. This study helps the operations managers at mobile phone service providers in Jordan to take proactive actions to improve their positions and avoid deterioration especially for the laggard. The new entrants for the Jordan market have better insight about the sources of competitive advantages, and the future of this industry. Further, the telecommunication commission in Jordan can benefit from this result in deciding whether to open the market for the new entrants or not. The customers especially the corporate customers have better insight about the most sustained service provider over time to maintain the relationship with him.

This study investigated the practices of limited number of service providers in one country. Further studies could be extended to include other service providers at regional level. This study did not examine the impact of country context on the operations competitive advantages. Also it did not 
examine the impact of corporation's characteristics on the operations competitive advantages. Moreover, this study did not examine the impact of operations competitive advantages on the performance of corporations as the realized market share, and profitability.

\section{REFERENCES}

Aaltonen, J., \& Östermark, R. (1998). Mixed markov modelling of financial success: Empirical evidence with Swedish data. Kybernetes, 27(1), pp. 54-70.

Beheshti, H. M. (2004). Gaining and sustaining competitive advantage with activity based cost management system. Industrial Management \& Data Systems, 104(5), pp. 377-383.

Business Monitor International (2011) Jordan Telecommunication Report Q3 2011, available at $\mathrm{http} / /$ www.fastmr.com/catalog/publishers.aspx?pubid $=1010$ (accessed on 28 July 2011).

Chang, G. (2006). Bayesian Markov mixture of normals approach to modeling financial returns. Studies in Economics and Finance, 23(2), pp. 141-158.

Du, L. (2007). Acquiring competitive advantage in industry through supply chain integration: a case study of Yue Yuen Industrial Holdings Ltd.Journal of Enterprise Information Management, 20(5), pp. 527-543.

Felzensztein, C., \& Gimmon, E. (2014). Competitive advantage in global markets: the case of the salmon industry in Chile. European Business Review, 26(6), pp. 568-587.

Hill, T., \& Hill, A. (2009). Manufacturing strategy: text and cases. Palgrave Macmillan.

Hua, S., Ranjan Chatterjee, S., \& Jingliang, C. (2011). Achieving competitive advantage in service supply chain: evidence from the Chinese steel industry.Chinese Management Studies, 5(1), pp. 68-81.

Information Technology Association-Jordan (2011) ICT Sector Classification and Statistics 2009, available at http://www.intaj.net/node/306 (accessed on 14 September 2011).

International Telecommunication Union (2010) World Telecommunication Report 2010: Monitoring the Wises Targets Amid-Term Review, ITU, Geneva, Switzerland.

Javalgi, R. R. G., Gross, A. C., Benoy Joseph, W., \& Granot, E. (2011). Assessing competitive advantage of emerging markets in knowledge intensive business services. Journal of Business \& Industrial Marketing,26(3), pp. 171-180.

Kazemi, A, Modarres M., Mehregan M.R., Neshat N. and Foroughi. A. (2011), " A Markov Chain Grey Forecasting Model: A Case Study of Energy Demand of Industry Sector in Iran" 3rd International Conference on Information and Financial Engineering: Singapore.

Lee, J., Kim, Y., Lee, J. D., \& Park, Y. (2006). Estimating the extent of potential competition in the Korean mobile telecommunications market: Switching costs and number portability. International Journal of Industrial Organization, 24(1), pp. 107-124.
Lee, T. R., Huang, H. L., Huang, B. W., \& Chen, S. Y. (2007). Milk supply chain and development strategy. International Journal of Services and Operations Management, 3(2), pp. 227-244.

Leseure, M. (2010). Organisational design alternatives within international operations networks: a transaction cost perspective. International Journal of Services and Operations Management, 7(4), pp. 419-439.

Mehmood, R., \& Lu, J. A. (2011). Computational Markovian analysis of large systems. Journal of Manufacturing Technology Management, 22(6), pp. 804-817.

Migdadi, Y. K. A. A. (2012). The order winners' operations strategy of mobile phone service providers in developing economies: the case of Jordan. International Journal of Services and Operations Management, 13(3), pp. 329-360.

Nyandwaki, Mose Job, et al. (2014) "Application of Markov Chain Model in Studying progression Of Secondary School Students by Sex During The Free Secondary Education: A Case Study of Kisii Central District." Mathematical Theory and Modeling, 4(4), pp. 73-84.

O'Shannassy, T. (2008). Sustainable competitive advantage or temporary competitive advantage: improving understanding of an important strategy construct. Journal of Strategy and Management, 1(2), pp. 168-180.

Passemard, D., \& Kleiner, B. H. (2000). Competitive advantage in global industries. Management Research News, 23(7/8), pp. 111-117.

Render, B.; Stair, R.M.; and Hanna, M.E. (2012). Quantitative analysis for management, eleventh edition, Pearson Education Limited, England

Skinner, W. (1969) 'Manufacturing-missing link in corporate strategy', Harvard Business Review, Vol. 47, No. 3, pp. 136145.

Skinner, W. (1974) 'The focused factory', Harvard Business Review, 52, (3): pp. 113-121.

The Royal Bank of Scotland (2011) Jordan Rasmala Investment Bank/Telecom, available at http://www'rasmala.com (accessed on 25 July 2011).

Uslu, A. Y. P. A. R., \& Cam, T. U. N. C. A. Y. (2014). Analysis of Brand Loyalty with Markov Chains. Available at: http://www. opf. slu. cz/vvr/akce/turecko/pdf/Uslu. Pdf, (accessed on $7^{\text {th }}$ March 2016)

Paiva, E. L., \& Vieira, L. M. (2011). Strategic choices and operations strategy: a multiple cases study. International Journal of Services and Operations Management, 10(2), pp. 119-135.

Ward, P. T., Bickford, D. J., \& Leong, G. K. (1996). Configurations of manufacturing strategy, business strategy, environment and structure.Journal of management, 22(4), pp. 597-626.

Wheel Wright, S. C. (1984). Manufacturing strategy: defining the missing link. Strategic management journal, 5(1), pp. 77-91.

Zhang, D., \& Zhang, X. (2009). Study on forecasting the stock market trend based on stochastic analysis method. International Journal of Business and Management, 4(6), p.163. 
APPENDIX A: THE DATA RELATED TO OPERATIONS COMPETITIVE CAPABILITY OF MOBILE PHONE SERVICE PROVIDERS IN JORDAN (SOURCE: MIGDADI, 2012)

\begin{tabular}{|c|r|r|r|r|c|c|}
\hline Corporation & $\begin{array}{c}\text { Network } \\
\text { coverage }\end{array}$ & $\begin{array}{c}\text { Diversity } \\
\text { of offers }\end{array}$ & $\begin{array}{c}\text { Cost of } \\
\text { calls } \\
\text { service }\end{array}$ & $\begin{array}{c}\text { Diversity } \\
\text { of basic } \\
\text { services }\end{array}$ & $\begin{array}{c}\text { Diversity of } \\
\text { entertainment } \\
\text { services }\end{array}$ & $\begin{array}{c}\text { Network } \\
\text { accessibility }\end{array}$ \\
\hline Zain (2005) & $85 \%$ & 17 & 4.07 & 9 & 7 & $18 \%$ \\
Zain (2011) & $98 \%$ & 20 & 1.88 & 10 & 9 & $15 \%$ \\
\hline Orange (2005) & $90 \%$ & 23 & 4.32 & 8 & 9 & $22.5 \%$ \\
Orange (2011) & $97 \%$ & 27 & 3.25 & 8 & 13 & $15 \%$ \\
\hline Umniah (2005) & $66 \%$ & 9 & 0.68 & 10 & 9 & $39.1 \%$ \\
Uminah (2011) & $68 \%$ & 17 & 0.91 & 12 & 12 & $34.4 \%$ \\
\hline
\end{tabular}

\section{APPENDIX B: THE VECTORS OF COMPETITIVE POSITION} PROBABILITIES AND MATRICES OF TRANSITION PROBABILITIES

Appendix (B-1) network coverage

\begin{tabular}{|c|c|c|c|c|c|}
\hline & & & Zain & Orange & Umniah \\
\hline Zain & Orange & Umniah & 1 & 0 & 0 \\
\hline \multirow[t]{2}{*}{ (0.36 } & 0.36 & $0.28)$ & 0.005 & 0.995 & 0 \\
\hline & & & 0.02 & 0 & 0.98 \\
\hline
\end{tabular}

Appendix (B-2) diversity of offers

\begin{tabular}{|c|c|c|c|c|c|}
\hline & & & Zain & Orange & Umniah \\
\hline Zain & Orange & Umniah & 0.97 & 0 & 0.03 \\
\hline \multirow[t]{2}{*}{$(0.35$} & 0.47 & $0.18)$ & 0 & 0.95 & 0.05 \\
\hline & & & 0 & 0 & 1 \\
\hline
\end{tabular}

Appendix (B-3) calls rate per minute

$\begin{array}{rrrrrr} & & & \text { Zain } & \text { Orange } & \text { Umniah } \\ \text { Zain } & \text { Orange } & \text { Umniah } & 1 & 0 & 0 \\ (0.13 & 0.12 & 0.76) & 0 & 1 & 0 \\ & & & 0.15 & 0.04 & 0.81\end{array}$

Appendix (B-4) number of basic services

\begin{tabular}{|c|c|c|c|c|c|}
\hline & & & Zain & Orange & Umniah \\
\hline Zain & Orange & Umniah & 1 & 0 & 0 \\
\hline \multirow[t]{2}{*}{$(0.33$} & 0.30 & $0.37)$ & 0 & 1 & 0 \\
\hline & & & 0 & 0.03 & 0.97 \\
\hline
\end{tabular}

Appendix (B-5) network coverage

\begin{tabular}{rrr|rrr|} 
& & & Zain & Orange & Umniah \\
Zain & Orange & Umniah & 1 & 0 & 0 \\
$(0.23$ & 0.28 & $0.49)$ & 0.007 & 0.95 & 0.043 \\
& & & 0 & 0 & 1
\end{tabular}

Appendix (B-6) number of entertainment services

$\begin{array}{rrrrrr} & & & \text { Zain } & \text { Orange } & \text { Umniah } \\ \text { Zain } & \text { Orange } & \text { Umniah } & 0.98 & 0.02 & 0 \\ (0.28 & 0.36 & 0.36) & 0 & 1 & 0 \\ & & & 0 & 0.007 & 0.993\end{array}$


Dr. Yazan Khalid Abed-Allah Migdadi is an Associate professor of operations management at business department, Yarmouk University, Jordan. He was awarded Ph.D. in operations management from Bradford University, UK, also awarded BA and MBA from Yarmouk University, Jordan. He worked as a teaching assistant and a researcher of operations and information management at Bradford University, School of Management, UK. His main research interest is reporting operations strategy: best practices, taxonomies, process, and typologies. 